\title{
Greining á orðanotkun í lesskilnings- og náttúruvísindahlutum PISA 2018: Samanburður á íslensku pýðingunni og enska textanum
}

\author{
Auður Pálsdóttir og Sigríður Ólafsdóttir
}

$\checkmark$ Abstract $\rightarrow$ Um höfundana About the authors $\rightarrow$ Heimildir

\begin{abstract}
Markmið pessarar rannsóknar var að kanna samræmi í orðtíðni í íslenskum og enskum textum á lesskilnings- og náttúruvísindahluta PISA-prófanna 2018. Ef pýđing texta í albjóðlegu prófi er pyngri eða léttari en sami texti á upprunalega málinu getur pað haft áhrif á skilning og skekkt samanburð milli tungumála.
\end{abstract}

Greindirvoru tveirtextarúrlesskilningshluta PISA 2018 ogtveirúrnáttúruvísindahlutanum. Notaður var orðtíðnilisti Íslenskrar risamálheildar og enskur orðtíðnilisti sem byggist á tveimur málheildum og er aðgengilegur í gegnum hugbúnaðinn VocabProfile. Orðin voru flokkuð eftir tíðni í fimm flokka. Ef munur var á tíðniflokki orða á íslensku og ensku var kannað hvort til væri samheiti fyrir íslenska orðið í sama tíðniflokki og pað enska og lengd samheita borin saman.

Niðurstöður benda til að hlutfall algengustu orða sé lægra í textum íslensku pýðingarinnar en í ensku frumtextunum og að hlutfall orða í flokki sjaldgæfustu orðanna sé umtalsvert hærra í íslensku textunum en peim ensku. Pá virðist dreifing orða á milli orðtíðniflokka vera jafnari í ensku en íslensku pýðingunni. Fram komu vísbendingar um ákveðið ósamræmi og ójafnvægi sem fólst 1 að tveir priðju hlutar peirra íslensku orða, sem féllu í annan tíðniflokk en ensku orðin, voru sjaldgæfari en samsvarandi ensk orð. Í ljós kom að fækka hefði mátt orðum í ólíkum orðtíðniflokkum með bví að nota íslenskt samheiti í sama orðtíðniflokki og enska orðið og að draga hefði mátt enn frekar úr ósamræminu með pví að velja samheiti úr nærliggjandi tíðniflokki. Hlutfall íslenskra samheita sem voru algengari og lengri var yfir 30\% í textunum fjórum. Niðurstöðurnar gefa tilefni til að endurskoða purfi leiðbeiningar OECD og beina pví til pýðenda að peir taki mið af orðtíðnilistum við val á orðum.

Efnisorð: PISA, pýðingar, orðaforði, orðtíðni, lesskilningur, náttúruvísindi

\section{Inngangur}

PISA-rannsóknin (e. The Programme for International Student Assessment) byggist á prófum sem lögð eru fyrir 15 ára nemendur í fjölmörgum ríkjum innan og utan OECD (e. Organisation for Economic Co-operation and Development). Prófin eru í premur hlutum; í lesskilningi, læsi á stærðfræði og læsi á náttúruvísindi, og samin á ensku og frönsku. Prófin eru síðan býdd á hin ýmsu tungumál pátttökubjóða. Til að ná fram alpjóðlegum samanburði er grundvallaratriði að 
samræmi sé á milli prófa á ólíkum tungumálum og pess vegna eru gerðar ítrustu kröfur um nákvæmni í pýðingum. Ef pýddur texti verður of erfiður hamlar pað nemendum að skilja og vinna með textann, umfram pá sem lesa textann á upprunalega tungumálinu. Í lesskilningshluta prófsins reynir til að mynda á hæfni nemenda til að finna, velja og meta upplýsingar í texta, nýta bakgrunnspekkingu sína og að vega og meta ólík sjónarhorn (LaRusso o.fl., 2016; OECD, 2016). Dví getur of pungur texti, með of flóknum orðum, orðið til trafala pannig að lesandinn nái síður að beita viðeigandi lestrartækni.

Degar PISA-prófin voru lögð fyrir í fyrsta skipti árið 2000 var frammistaða íslenskra ungmenna $i ́$ lesskilningi á pari við meðaltal OECD en hefur síðan hrakað verulega, samtals um 25 stig sem samsvarar rúmlega hálfu skólaári. Afturförin birtist einnig í pví að hlutfall nemenda á lægstu hæfniprepunum hefur hækkað en lækkað á efstu prepunum (Menntamálastofnun, 2017; Sigríður Ólafsdóttir og Baldur Sigurðsson, 2017).

Degar horft er til niðurstaðna PISA í læsi á náttúruvísindi frá árinu 2006 til 2015 hefur frammistöðu íslenskra nemenda farið aftur og gildir pað um alla undirpætti, pekkingarsvið og efnissvið náttúruvísinda. Pá stendur mikill meirihluti OECD-ríkja betur að vígi en Ísland á sviði læsis á náttúruvísindi (Menntamálastofnun, 2017).

Líkt og í lesskilningshluta PISA-prófa sýna niðurstöđur fyrir læsi á náttúruvísindi fjölgun nemenda í lægstu hæfniprepum og fækkun í efstu hæfniprepunum. Hæfniprep 2 er séð sem lágmarksfærni til að nemandi geti nýtt færnina sér til gagns við úrlausnir á verkefnum daglegs lífs sem bíða hans eftir grunnskóla. Hlutfall íslenskra nemenda á hæfniprepi 2 eða neðar hækkaði úr 47\% árið 2006 1́ 55\% árið 2015. Degar rýnt er nánar í pekkingarsvið læsis á náttúruvísindi má sjá að íslensku nemendurnir eru einum til tveimur árum á eftir jafnöldrum sínum í Noregi, Svípjóð og Danmörku í eðlis- og efnafræði. Pá benda niðurstöðurnar til pess að íslenskum unglingum hafi farið mest aftur á pekkingarsviði jarðvísinda og stjörnufræði (e. earth and space) (Auður Pálsdóttir, 2017).

Margt bendir til pess að orðaforði sé veigamikill áhrifavaldur á frammistöðu nemenda í lesskilningi og veiti forspá um hvort peir lendi undir lágmarksviðmiðum í PISA (Arnbak, 2010; Freyja Birgisdóttir, 2016; LaRusso o.fl., 2016; Sigríður Ólafsdóttir, Freyja Birgisdóttir, Hrafnhildur Ragnarsdóttir og Sigurgrímur Skúlason, 2016). Minnkandi áhugi á náttúrufræði er m.a. rakinn til pess að nemendur eigi stöðugt erfiðara með námið pví orðaforði og málskilningur er slakur. Til að efla djúpan lesskilning benda rannsóknir til svo ekki verður um villst að efla purfi hærra stigs orðaforða nemenda (p.e. lágtíðniorða) og beita purfi lesskilningsaðferðum í öllum námsgreinum (Auður Pálsdóttir, 2017).

Í samanburði á milli landa eins og í PISA parf að vera sem best samræmi á hvernig reynir á orðaforða nemenda svo réttmætis sé gætt og prófin mæli pað sem peim er ætlað að mæla. Dví var í pessari rannsókn rýnt í orðaval í íslenskri pýðingu PISA 2018.

\section{Fræðilegur grunnur}

OECD gefur út leiðarvísi fyrir pýðendur prófanna (OECD, 2016). Mælt er með að bæði enska og franska útgáfan séu pýddar, hvor í sínu lagi, og pær bornar saman. Pess er pó getið að í sumum löndum sé illframkvæmanlegt að pýða bæði tungumálin og pá purfi að gæta enn meiri nákvæmni. Hér á landi hefur aðeins verið byggt á ensku útgáfunni (Menntamálastofnun, 2016; OECD, 2016). Löggiltir pýðendur eru ráðnir til verksins, peir eru allir kennarar og hafa kennt eða starfa við kennslu í grunnskólum og framhaldsskólum og er ferlið sambærilegt í öllum pátttökulöndunum. Verkferlið er skýrt á vef Menntamálastofnunar (2016).

Sterkasta forspá um frammistöðu nemenda í lesskilningshluta PISA er orðaforði peirra (Arnbak, 2010; Freyja Birgisdóttir, 2016). Skilningur nemenda á orðum er forsenda pess að peir geti ráðið 
í merkingu textans og unnið með hann. Í íslenskri rannsókn kom í ljós að 98\% orðskilningur er nauðsynlegur fyrir góðan lesskilning, og ef nemendur skilja ekki tvö orð eða fleiri af 100 ná peir ekki að átta sig nægilega vel á innihaldi hans (Erla Lind Dórisdóttir, 2017). Er pað í samræmi við niðurstöður rannsókna með nemendum sem fást við enskan texta (Hu og Nation, 2000; Laufer og Ravenhorst-Kalovski, 2010). Dví er ljóst að hvert orð í texta skiptir máli, p.e. hvort hann skilst eða ekki.

Í leiðbeiningum OECD (2016) eru sett almenn viðmið um hvernig pyngd orða tengist tíðni peirra, lengd eða sérhæfingu án tillits til tungumáls. Um pýðingar milli mála segir að velja eigi sambærileg orð að pyngd og sérhæfingu í merkingu og pannig skuli forðast að velja flóknari eða einfaldari orð en eru í upphaflegu útgáfunni. Á pað við í býðingu á fyrirmælum, textum og svarmöguleikum. Til að meta hvort orð eru flókin eða einföld segir í leiðbeiningum OECD að lengri orð hafi tilhneigingu til að vera flóknari, tæknilegri og/eða óhlutlægri en stutt orð. Pýðendur eigi að forðast að velja erfið orð með pví að nota orð eða orðasambönd sem innihalda algengari orð. Á hinn bóginn eigi ekki að pýða orð og orðasambönd sem tilheyra daglegu lífi með tæknilegri orðum eða orðum sem frekar tilheyra ritmáli (OECD, 2016, bls. 11). Í leiðbeiningum OECD segir:

It is no coincidence that average word length and sentence length almost always feature among indices of complexity used in readability formulas, regardless of the language for which the formulas have been developed. Longer words tend to be less frequent, more technical and/or more abstract than short words ... As a general rule, translators should try their best to avoid translating difficult words in the text by using easier words, or paraphrases that use more common terms. Conversely, everyday terms used in the source materials should not be translated as more 'technical', 'scientific' or 'literary' expressions. (OECD, 2016, bls. 11)

Pannig er í leiðarvísi OECD ekkert fjallað um samsett orð sem eru eðlilega lengri en ósamsett orð. Íslensk samsett orð innihalda iðulega algeng orð eða orðhluta og eru pví gegnsæ og auðskilin. Sem dæmi má nefna orðið nafnlaus en samsvarandi enska orðið anonymous er af grískum uppruna og pví líklegra að pað sé torskildara en íslenska orðið.

Til að bera saman áreiðanleika pýðinga hafa rannsakendur gert tölfræðilega úrvinnslu á svörum nemenda, par sem borin hefur verið saman dreifing stiga eftir einstökum prófum og prófpáttum (e. DIF, difference item functioning) (Chen og Jiao, 2014; Grisay, de Jong, Gebhardt, Berezner og Halleux-Monseur, 2007; Oliveri og Ercikan, 2011). Örfáar rannsóknir hafa beinst að pví hvort samræmi sé í orðavali frumtexta PISA og pýðinga (Hopfenbeck o.fl., 2018). Ekki er vitað um samanburð á tíðni orða í pýðingum og upprunalegum texta PISA-prófa út frá málheildum, p.e. orðasöfnum sem byggjast á fjölda margs konar texta.

Arffman (2010) bar saman finnsku pýðinguna og enska textann í lesskilningshluta prófsins sem lagt var fyrir árið 2000. Hún komst að pví að finnsku orðin voru að jafnaði lengri en pau ensku. Á hinn bóginn var finnski textinn iðulega óformlegri og pví auðveldari en sá enski. Ástæðan fyrir pví reyndist vera að í finnsku er lítið sem ekkert af erlendum orðum en aftur á móti eru mörg orð í ensku af erlendum uppruna. Pó kom í ljós að ýmist of erfiður eða of léttur texti í samanburði við upprunalega enska textann varð til pess að jafnvægi náðist að einhverju leyti, hvor skekkjan vóg upp á móti hinni. Arffman dró pá ályktun að nauðsynlegt væri að vega og meta hvert og eitt orð í bádum málum til að fá nákvæman samanburð á upprunalega textanum og pýðingunni.

Ásdís Bergpórsdóttir (2016) greindi íslensk orð í náttúruvísindahluta PISA-prófsins árið 2015 og bar saman við upphaflegu ensku útgáfuna. Aðferðin sem hún beitti við að meta flækjustig íslenskra orða fólst í að skoða hve oft orðin birtust á leitarsíðunni Google.com. Hún komst að pví að íslensku orðin voru iðulega of flókin miðað við pau ensku. Dá benti hún á dæmi um rangar pýðingar á orðum. 
Sterk tengsl á milli tíðni orða og pess hve líklegt er að einstaklingar pekki orðin hafa komið fram í fjölmörgum erlendum rannsóknum (Baayen, Wurm og Aycock, 2007; Balota, Yap og Cortese, 2006; Gardner, Rothkopf, Lapan og Lafferty, 1987; Meunier og Segui, 1999; Oldfield og Wingfield, 1965). Dví algengari sem orðin eru peim mun líklegra er að einstaklingar pekki og skilji pau orð.

Tíðni orða er hægt að finna í orðtíðnilistum sem byggja á orðasöfnum, svokölluðum málheildum. Síðustu tvo áratugi hafa orðið miklar tæknilegar framfarir í tölvuvinnslu stórra málheilda sem byggja á tungumáli samtímans (Biber og Reppen, 2015; Biber, Reppen og Friginal, 2010; Martinez og Schmitt, 2015; Nation, 2016; Reppen, 2010). Orðum er raðað eftir pví hve oft pau koma fyrir í málheildinni, pað algengasta er númer eitt og svo koll af kolli. Slíkar upplýsingar eru einkar mikilvægar til að finna orð sem mikilvægt er að nemendur pekki (Cobb, 2007; Dale og O'Rourke, 1981; Hiebert, Scott, Castaneda og Spichtig, 2019). Orðtíðnilistar hafa pó pær takmarkanir að par er að finna einstök orð en ekki orðasambönd og ekki er tekið tillit til margvíslegrar merkingar sem sama orð í sama orðflokki getur haft.

Í hverju tungumáli eru fá orð sem eru mjög algeng bæði í tali og riti, svokölluð hátíðniorð, en ótal mörg orð sem koma sjaldan fyrir, svokölluð lágtíðniorð (Friðrik Magnússon, 1988; Nation, 2001). Rannsóknir hafa leitt í ljós að nemendur pekkja lágtíðniorðin í mismiklum mæli, en pekking á slíkum orðum hefur mikil áhrif á lesskilning peirra (Biemiller, 2008; Roessingh, 2016). Af pví má ráđa að hlutfall lágtíðniorða parf að vera sambærilegt á hinum ýmsu tungumálum til að samanburður á milli ríkja sé réttmætur (sjá t.d. Romanko, 2017).

Til að skilja betur frammistöðu 15 ára íslenskra nemenda og breytingar par á er mikilvægt að rýna í niðurstöður PISA-prófanna hér á landi (Auður Pálsdóttir, 2017; Sigríður Ólafsdóttir og Baldur Sigurðsson, 2017). Ein ástæða neikvæðrar próunar á Íslandi er sennilega sú að bóklestur barna og unglinga hefur farið minnkandi síðustu áratugi (Freyja Birgisdóttir, 2016; Rannsóknir og greining, 2016). Lesskilningur eykst með ástundun lestrar og pví er hrakandi færni barna og unglinga til að nýta sér ritaðan texta óhjákvæmileg afleiðing pess að pau lesa minna en áður. Pó má gera ráð fyrir að sama eigi við ungmenni annars staðar í heiminum, að vegna aukinnar tölvunotkunar og samhliða sífjölbreytilegra framboði afpreyingarefnis verji pau minni tíma í lestur. Íslenskan er pó í hópi peirra tungumála sem standa sérstaklega illa í stafrænum heimi pví tiltölulega lítið er til af íslensku efni á veraldarvefnum. Íslenskt tungumál er einmitt eitt peirra mála sem eiga á hættu að deyja út með komandi kynslóðum ef ekki verður lögð áhersla á að gera pau gjaldgeng í stafrænum heimi (Eiríkur Rögnvaldsson, Kristín M. Jóhannsdóttir, Sigrún Helgadóttir og Steinpór Steingrímsson, 2012).

Slæm staða íslenskra nemenda í samanburði við jafnaldra peirra erlendis í lesskilningi og læsi á náttúruvísindi í PISA kallar á nánari rýni í nákvæmni býđingar frá ensku yfir á íslensku. Markmið pessarar rannsóknar var pví að kanna samræmi í orðtíðni í íslenskum og enskum textum lesskilnings- og náttúruvísindahluta PISA-prófanna 2018. Eins og áður segir er í leiðbeiningum OECD (2016) um pýðingar PISA-prófanna tekið fram að pyngd orða og sérhæfing í merkingu sé mikilvægt viðfangsefni pýðenda, en jafnframt bent á að lengri orð hafi tilhneigingu til að vera sjaldgæfari og pví purfi pýðendur að forðast að pýða erfið orð með auðveldari orðum eða umorða erfið orð með auðveldara orðalagi (bls. 11). Í pessu ljósi pótti fróðlegt að skoða sérstaklega íslensku orðin sem féllu ekki í sama tíðniflokk og samsvarandi enska orðið og bera saman lengd íslenska orðsins við samheiti pess í sama eða nærliggjandi tíðniflokki og enska orðið.

Mótaðar voru fjórar rannsóknarspurningar sem öflun og greining gagna snerist um:

Hvert er hlutfall orða í fimm tíðniflokkum í íslensku og ensku í lesskilnings- og náttúruvísindatextum PISA-prófanna 2018?

Hversu hátt hlutfall pýddra íslenskra orða fellur í annan tíðniflokk en samsvarandi ensk orð í upprunalegu textunum? 
Fyrir hversu hátt hlutfall peirra orða hefði mátt velja samheiti sem fellur í sama eða nærliggjandi tíðniflokk og samræmist pannig betur enska orðinu?

Hversu oft hlutfallslega er algengara íslenska orðið lengra en sjaldgæfara samheiti pess?

Rannsókn af pessum toga og svör við spurningum hennar getur verið hvati fyrir aðrar pjóðir í peirri viðleitni að samanburður á milli landa verði réttmætari.

\section{Aðferð}

Valdir voru af handahófi fjórir textar úr PISA-prófinu árið 2018, tveir textar úr lesskilningshlutanum (textinn R055 um kóngulær og R406 um brúðumeistara) og tveir textar úr náttúruvísindahlutanum (textinn S527 um aldauða risaeðla og S326 um mjólk) og orðaval í íslensku pýðingunni var borið saman við ensku textana. Greiningin hófst í lok mars 2018, p.e. á svipuðum tíma og prófin voru lögð fyrir á Íslandi. Ađgengi að PISA-prófinu 2018 fékkst hjá Menntamálastofnun.

\section{Val á málheildum og orðtíðnilistum}

Greining pessara texta PISA-prófsins byggir á orðtíðnilistum sem koma úr íslenskum og enskum málheildum. Drjár umfangsmiklar málheildir hafa fengist úr rannsóknum á íslensku máli. Úr hverri peirra hafa verið unnir orðtíðnilistar par sem hvert orð er sett fram sem svokallað flettiorð, eða lemma, p.e. ein lemma er hvert orð í öllum peim myndum sem pað birtist í textanum (Friðrik Magnússon, 1988, bls. 2).

Íslensk orðtíðnibók (Friðrik Magnússon og Stefán Briem, 1991) byggir á textasafni úr íslenskum og pýddum sögum, ævisögum, fræðilegum textum, ásamt barna- og unglingabókum, samtals um fimm hundruð púsund lesmálsorðum. Fjöldi lesmálsorða í texta er í raun fjöldi orðanna í textanum, alveg sama hvort sömu orðin koma oftar en einu sinni fyrir og hvort um mismunandi beygingarmyndir er að ræða.

Í Markaðri íslenskri málheild má finna um 25 milljónir lesmálsorða úr fjölbreyttum tölvutækum textum sem safnað var á árunum 2006-2010 (Stofnun Árna Magnússonar í íslenskum fræðum, e.d.). Meirihlutinn kemur úr útgefnum bókum, dagblöðum og tímaritum, en innan við 15\% eru textar frá opinberum aðilum eins Alpingi, ráđuneytum og úr dómum.

Til að renna styrkari stoðum undir rannsóknir á íslensku máli var ráðist í gerð nýrrar málheildar sem kallast Íslensk risamálheild. Hún er safn um 1300 milljón lesmálsorða par sem stærstur hlutinn kemur úr margs konar vefmiðlum, prentuðum blöðum, ljósvakamiðlum og opinberum textum. Um pað bil 86\% textanna eru frá pví eftir árið 2000, og rúmlega 94\% frá pví eftir árið 1980. Í pessari rannsókn var byggt á Risamálheildinni en sóttur var rafrænn orðtíðnilisti sem aðgengilegur er til niðurhals á vefnum malfong.is og unninn var með sérsmíðuðu forriti upp úr gögnum Risamálheildarinnar (Steinpór Steingrímsson, Sigrún Helgadóttir, Eiríkur Rögnvaldsson, Starkaður Barkarson og Jón Guðnason, 2018; Stofnun Árna Magnússonar í íslenskum fræðum, 2017, e.d.).

Til að greina tíðni orða í ensku textunum var notaður orðtíðnilisti sem byggist á tveimur málheildum og aðgengilegur er í gegnum hugbúnaðinn VocabProfile (Cobb, e.d.). Dessar málheildir voru valdar pví pær samræmdust best Risamálheildinni og orðtíðnilistinn samanstendur af lemmum. Annars vegar var pað enska málheildin The New General Service List (NGSL; Browne, Culligan og Phillips, 2013) sem byggir á 273 milljón lesmálsorðum úr Cambridge English Corpus (CEC), með töluðu og rituðu nútímamáli í dagblöðum, á vefmiðlum, í bókum, tímaritum, útvarpi, skólum, háskólum og á vinnustöðum. Hins vegar var pað The New Academic Word List (NAWL) sem felur í sér vinnslu á 288 milljón lesmálsorðum sem koma úr fagbókum á 
toppsölulistum og úr fræðilegum erindum. Dessum tveimur málheildum er sérstaklega ætlað að vinna saman.

PISA er ætlað að varpa ljósi á færni nemenda við lok grunnskóla til að taka virkan pátt í samfélaginu og ná árangri í námi (OECD, 2017). Bæði íslenski orðtíðnilistinn og sá enski samanstanda af orðum (p.e. lemmum) sem ætla má að gegni stóru hlutverki á peirri vegferð. Orðin tilheyra pó einna helst heimi hinna fullorðnu. Pá virðist vanta í Risamálheildina orðaforða sem er að finna t.d. í námsefni og textum sem sérstaklega eru ætlaðir ungu fólki en eins og áður segir inniheldur önnur enska málheildin tungumál sem notað er í skólum.

\section{Greining gagna}

Degar ensku textarnir voru keyrðir í gegnum hugbúnaðinn $v$ fékkst samstundis sundurliðun á orðum byggð á tíðni peirra. Orð sem féllu í hóp algengustu 1000 orðanna fengu bláan lit, næstu 1000 grænan, næstu 1000 bleikan, næstu 1000 gulan og orð sem voru sjaldgæfari eða fundust ekki í málheildinni fengu rauðan lit.

Orðin í íslensku pýðingunni voru borin saman við orðtíðnilista Risamálheildarinnar og flokkuð á sama hátt í fimm tíðniflokka. Pannig fengust upplýsingar um hversu hátt hlutfall orða féll í hvern tíðniflokk á báđum málum og hvort býdd íslensk orð tilheyrðu sama tíðniflokki og ensku orðin.

Enska hugbúnaðarforritið og Risamálheildin greina tíðni einstakra orða en ekki orðasambanda. Dví var farin sú leið að tíđni einstakra íslenskra orða var fundin og ef pað voru fleiri en eitt samsvarandi ensk orð var skráð tíðni pess orðs sem lenti í sjaldgæfasta tíðniflokknum. Til að meta gildi samanburðarins var hugað að margræðni orða og pau ávallt rýnd í samhengi textanna og samkvæmt orðflokki.

Íslensk orð sem féllu ekki í sama orðtíðniflokk og samsvarandi ensk orð voru skráð í lista og leitað að samheitum peirra á vefsíðunum malid.is og snara.is til að athuga hvort samheiti væri til í sama eða nærliggjandi tíðniflokki og enska orðið, og hæfðu samhengi textanna. Fyrrnefnda vefsíðan inniheldur Îslensk nútímamálsorðabók (Halldóra Jónsdóttir og Dórdís Úlfarsdóttir, 2018) sem gefur samheiti orða.

Að lokum var borin saman lengd íslensku samheitanna, p.e. fjöldi bókstafa í hverju orði, til að kanna í hvaða tilvikum algengara samheitið væri lengra en pað sjaldgæfara.

\section{Niðurstöður}

Eins og áđur kom fram var markmið pessarar rannsóknar að kanna samræmi í orðtíðni í íslenskum og enskum textum lesskilnings- og náttúruvísindahluta PISA-prófanna 2018.

Hér eru fyrst kynntar niðurstöður greiningar á hlutfalli orða í tíðniflokkunum fimm í textunum fjórum. Bá er gerð grein fyrir fjölda og hlutfalli pýddra orða sem falla í annan tíðniflokk en samsvarandi ensk orð í upprunalegu textunum. Næst er fjallað um fjölda og hlutfall peirra orða sem hefði mátt velja samheiti fyrir og samræmdist pannig betur tíðniflokki enska orðsins. Dar á eftir er tilgreint að hve miklu leyti algengara íslenska orðið er lengra en sjaldgæfara samheiti pess. Í lokin er samantekt á niðurstöðum.

\section{Hlutfall orða í hverjum orðtíðniflokki}

Greining á orðum byggðist á tíðni peirra og var peim skipt upp í fimm tíðniflokka. Dannig fengust upplýsingar um hlutfall orða í hverjum tíðniflokki. Niðurstöður má sjá í töflu 1 fyrir 
íslensku textana og töflu 2 fyrir ensku textana. Í hnotskurn sýna pær að hlutfall algengustu orða var lægra í öllum textum íslensku pýðingarinnar en ensku útgáfunnar og á sama hátt að hlutfall orða í flokki sjaldgæfustu orðanna var umtalsvert hærra í íslensku textunum.

Tafla 1. Fjöldi og hlutfall orða sem féll í hvern tíðniflokk í íslensku PISA-textunum 2018.

\begin{tabular}{|c|c|c|c|c|c|c|c|c|c|c|c|}
\hline \multirow[t]{3}{*}{$\begin{array}{l}\text { Heiti PISA-texta } 2018 \text { í } \\
\text { íslenskri pýdingu }\end{array}$} & \multirow{3}{*}{$\begin{array}{l}\text { Heildar- } \\
\text { fjöldi orða í } \\
\text { texta }\end{array}$} & \multicolumn{10}{|c|}{$\begin{array}{l}\text { Orðtíðniflokkar: Fyrstu púsund algengustu orðin } \\
\text { (blár) o.s.frv. }\end{array}$} \\
\hline & & \multicolumn{2}{|c|}{$\begin{array}{c}\text { Blár } \\
(\leq 1000)\end{array}$} & \multicolumn{2}{|c|}{ Grænn } & \multicolumn{2}{|c|}{ Bleikur } & \multicolumn{2}{|c|}{ Gulur } & \multicolumn{2}{|c|}{$\begin{array}{l}\text { Rauður } \\
(4000<)\end{array}$} \\
\hline & & fj. & $\%$ & fj. & $\%$ & fj. & $\%$ & fj. & $\%$ & $\mathrm{fj}$. & $\%$ \\
\hline Kóngulær (R055) & 254 & 180 & 70,9 & 11 & 4,3 & 6 & 2,4 & 4 & 1,6 & 53 & 20,9 \\
\hline Brúðumeistarinn (R406) & 487 & 374 & 76,8 & 18 & 3,7 & 5 & 1,0 & 8 & 1,6 & 82 & 16,8 \\
\hline Mjólk (S326) & 131 & 93 & 71,0 & 3 & 2,3 & 10 & 7,6 & 4 & 3,1 & 21 & 16,0 \\
\hline Aldauði risaeðlanna (S527) & 174 & 111 & 63,8 & 9 & 5,2 & 8 & 4,6 & 9 & 5,2 & 37 & 21,3 \\
\hline
\end{tabular}

^Tölustafir töldust ekki með

Tafla 2. Fjöldi og hlutfall orða sem féll í hvern tíðniflokk í ensku PISA-textunum 2018.

\begin{tabular}{|c|c|c|c|c|c|c|c|c|c|c|c|}
\hline \multirow[t]{3}{*}{$\begin{array}{l}\text { Heiti PISA-texta } 2018 \text { í } \\
\text { enskri útgáfu }\end{array}$} & \multirow{3}{*}{$\begin{array}{c}\text { Heildar- } \\
\text { fjöldi orða í } \\
\text { texta }\end{array}$} & \multicolumn{10}{|c|}{$\begin{array}{l}\text { Orðtíðniflokkar: Fyrstu púsund algengustu orðin } \\
\text { (blár) o.s.frv. }\end{array}$} \\
\hline & & \multicolumn{2}{|c|}{$\begin{array}{c}\text { Blár } \\
(\leq 1000)\end{array}$} & \multicolumn{2}{|c|}{ Grænn } & \multicolumn{2}{|c|}{ Bleikur } & \multicolumn{2}{|c|}{ Gulur } & \multicolumn{2}{|c|}{$\begin{array}{l}\text { Rauður } \\
(4000<)\end{array}$} \\
\hline & & fj. & $\%$ & fj. & $\%$ & fj. & $\%$ & fj. & $\%$ & fj. & $\%$ \\
\hline $\begin{array}{l}\text { Drugged spiders drop } \\
\text { stitches (R055) }\end{array}$ & 265 & 196 & 74,0 & 18 & 6,8 & 17 & 6,4 & 4 & 1,5 & 30 & 11,3 \\
\hline $\begin{array}{l}\text { The master of Kokeshi } \\
\text { dolls (R406) }\end{array}$ & 546 & 449 & 82,2 & 23 & 4,2 & 15 & 2,7 & 2 & 0,4 & 57 & 10,4 \\
\hline Milk (S326) & 143 & 127 & 88,8 & 4 & 2,8 & 3 & 2,1 & 2 & 1,4 & 7 & 4,9 \\
\hline $\begin{array}{l}\text { Extinction of the dinosaurs } \\
\text { (S527) }\end{array}$ & 192 & 138 & 71,9 & 15 & 7,8 & 19 & 9,9 & 2 & 1,0 & 18 & 9,4 \\
\hline
\end{tabular}

^Tölustafir töldust ekki með

Eins og sjá má í töflu 1 og 2 var hlutfall algengustu orđa (blár flokkur) lægra í pessum fjórum íslensku pýðingum en í ensku textunum. Pá var hlutfall orða í flokki sjaldgæefustu orðanna (rauður flokkur) umtalsvert hærra í íslensku textunum en peim ensku. Í milliflokkunum premur (grænn, bleikur og gulur) var hlutfallið hærra í ensku textunum sem sýnir að dreifing orða á milli orðtíðniflokka var jafnari en í íslensku býðingunni.

Pennan mun á milli tungumálanna má glögglega sjá á mynd 1 sem sýnir hlutfall orđa í hverjum tíðniflokki hvers texta, á íslensku og ensku. 


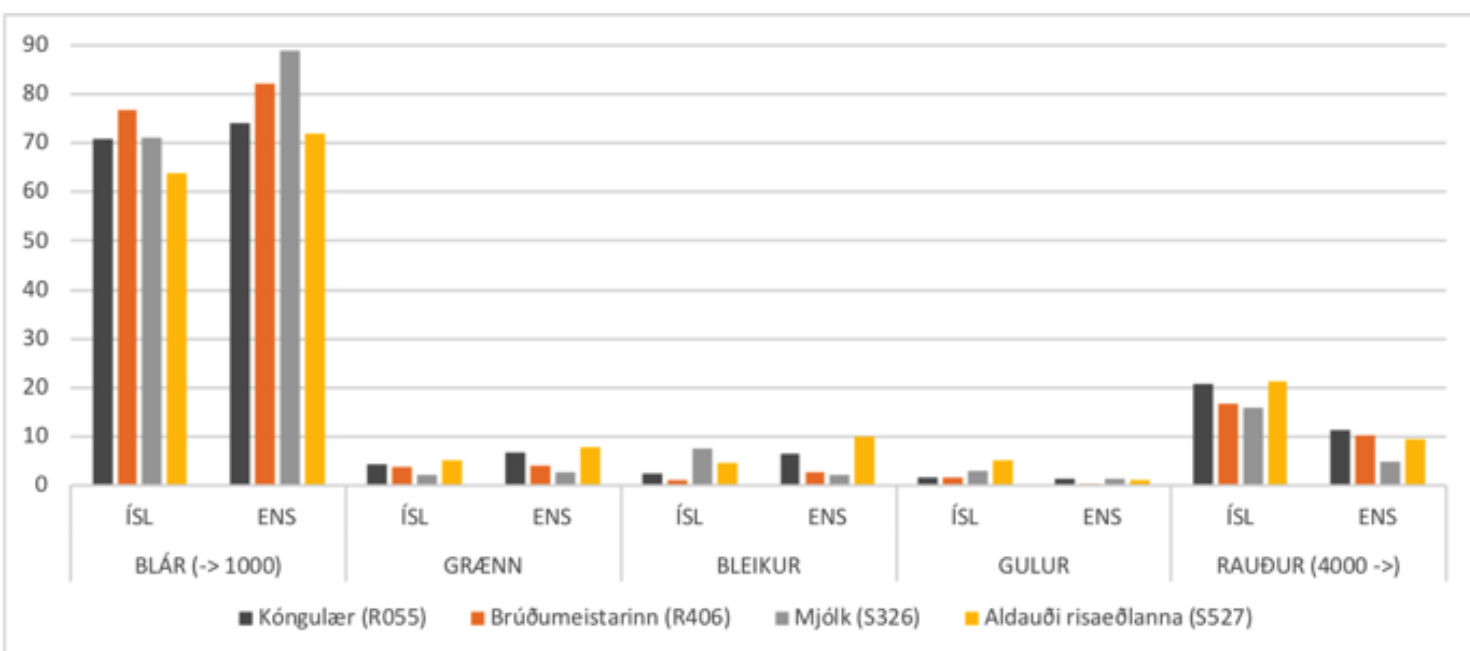

Mynd 1. Hlutfall orða í orðtíðniflokkunum fimm eftir textunum fjórum á íslensku og ensku.

Greining á peim orðum sem féllu í ólíkan tíðniflokk á íslensku en ensku er kynnt í töflu 3. Fram komu vísbendingar um ákveðið ójafnvægi sem fólst í að tveir priðju hlutar peirra íslensku orða sem féllu í ólíkan tíðniflokk en ensku voru sjaldgæfari en ensku orðin sem pau stóðu fyrir.

Tafla 3. Fjöldi og hlutfall orða sem féll í ólíkan tíðniflokk á íslensku en ensku í PISA 2018.

\begin{tabular}{|c|c|c|c|c|}
\hline $\begin{array}{l}\text { Heiti textanna } \\
\text { í PISA-prófinu } \\
2018\end{array}$ & $\begin{array}{l}\text { Heildarfjöldi } \\
\text { orða í íslensku } \\
\text { pýðingunni }\end{array}$ & $\begin{array}{l}\text { Fjöldi orða sem féll } \\
\text { í ólíkan tíðniflokk á } \\
\text { íslensku en ensku (\%) }\end{array}$ & $\begin{array}{c}\text { Íslensk orð } \\
\text { í sjaldgæfari } \\
\text { tíðniflokki } \\
\text { en ensk }\end{array}$ & $\begin{array}{l}\text { Í́slensk orð } \\
\text { í algengari } \\
\text { tíðniflokki } \\
\text { en ensk }\end{array}$ \\
\hline Kóngulær (R055) & 254 & $60(23,6 \%)$ & 36 & 24 \\
\hline $\begin{array}{l}\text { Brúðumeistarinn } \\
\text { (R406) }\end{array}$ & 487 & $74(15,2 \%)$ & 50 & 24 \\
\hline Mjólk (S326) & 131 & $67(51,1 \%)$ & 43 & 24 \\
\hline $\begin{array}{l}\text { Aldauði risaeðlanna } \\
\text { (S527) }\end{array}$ & 174 & $36(20,7 \%)$ & 32 & 4 \\
\hline SAMTALS & 1046 & $237(22,7 \%)$ & 161 & 76 \\
\hline
\end{tabular}

Í töflu 3 má sjá að hlutfall peirra íslensku orða sem lentu í öđrum tíðniflokki en samsvarandi ensk orð var $22,7 \%$. Af pessum orðum voru 68\% sem lentu í sjaldgæfari tíðniflokki (161 orð) en pau sem lentu í algengari tíðniflokki (76 orð). Detta er vísbending um ákveðið ósamræmi.

Pá var leitað að íslenskum samheitum sem gæetu leyst hin af hólmi og væru í sama eða nærliggjandi tíðniflokki og enska orðið. Í töflu 4 má sjá fjölda mögulegra samheita á íslensku sem hefði mátt nota og falla betur að tíðni samsvarandi enskra orða. Í ljós kom að bæta hefði mátt samræmið á íslensku pýðingunum við ensku textana með pví að velja samheiti sem falla betur að tíðniflokki enska orðsins. 
Tafla 4. Fjöldi samheita á íslensku sem gætu fallið í sama eða nærliggjandi tíðniflokk og sambærileg ensk orð í PISA 2018.

\begin{tabular}{|c|c|c|c|}
\hline $\begin{array}{l}\text { Heiti textanna í PISA- } \\
\text { prófinu } 2018\end{array}$ & $\begin{array}{c}\text { Fjöldi orða } \\
\text { í ólíkum } \\
\text { tíðniflokki á } \\
\text { íslensku en ensku }\end{array}$ & $\begin{array}{l}\text { Unnt að breyta í } \\
\text { islensk samheiti í } \\
\text { sama tíðniflokki } \\
\text { og enska orðið }\end{array}$ & $\begin{array}{c}\text { Unnt að breyta í íslensk } \\
\text { samheiti í nærliggjandi } \\
\text { tíðniflokki og enska } \\
\text { orðið }\end{array}$ \\
\hline Kóngulær (R055) & 60 & $\begin{array}{c}11 \\
\text { (9 i algengari } \\
2 \text { i sjaldgcfari) }\end{array}$ & $\begin{array}{c}4 \\
\text { (4 i algengari) }\end{array}$ \\
\hline Brúðumeistarinn (R406) & 74 & $\begin{array}{l}11 \\
\text { (10 i algengari } \\
1 \text { i sjaldgafari) }\end{array}$ & $\begin{array}{c}2 \\
\text { (1 i algengari } \\
1 \text { i sjaldgafari) }\end{array}$ \\
\hline Mjólk (S326) & 67 & $\begin{array}{c}9 \\
\text { (8 i algengari } \\
1 \text { i sjaldgefari) }\end{array}$ & $\begin{array}{c}6 \\
\text { (4 i algengari } \\
2 \text { i sjaldgafari) }\end{array}$ \\
\hline Aldauði risaeðlanna (S527) & 36 & $\begin{array}{c}2 \\
\text { (2 i sjaldgafari) }\end{array}$ & $\begin{array}{c}1 \\
\text { (1 i algengari) }\end{array}$ \\
\hline SAMTALS: & 237 & $\begin{array}{c}33 \\
\text { (29 i algengari } \\
6 \text { i sjaldgafari) }\end{array}$ & $\begin{array}{c}13 \\
\text { (10 } \mathrm{i} \text { algengari } \\
3 \text { i sjaldgafari) } \\
\end{array}$ \\
\hline
\end{tabular}

Eins og sjá má í töflu 4 hefði í mörgum tilvikum verið hægt að finna gjaldgeng orð sem falla betur að tíðniflokki samsvarandi enskra orða. Til dæmis hefði í sögunni um kóngulær vel mátt nota 11 íslensk samheiti í sama tíðniflokki og enska orðið og fækka pannig orðum í ólíkum tíðniflokki úr 60 (23,6\%) niður í 49 orð (19,3\%). Af pessum 11 íslensku samheitum hefðu níu orð fallið í algengari orðtíðniflokk en tvö í sjaldgæfari. Í viðbót hefði mátt velja fjögur íslensk samheiti sem voru í nærliggjandi tíðniflokki og enska orðið sem notað var í pýðingunni. Рað hefði bætt samræmið á íslensku pýðingunum við ensku textana enn frekar.

Eins og áđur kemur fram segir í leiðarvísi OECD (2016) að lengri orð hafi tilhneigingu til að vera sjaldgæfari en styttri orð. Pví var ákveðið að skoða sérstaklega íslensku orðin sem féllu ekki í sama tíðniflokk og samsvarandi ensk orð og bera saman lengd íslenska orðsins við samheiti pess í sama tíðniflokki og enska orðið, p.e. pegar samheiti fannst. Niðurstöður pessarar greiningar má sjá í töflu 5 sem sýnir að yfir priðjungur orða var algengari og lengri en samheiti peirra.

Tafla 5. Fjöldi (og hlutfall) íslenskra samheita sem eru algengari og lengri en orðin sem voru valin í íslensku pýðingu PISA 2018.

\begin{tabular}{cccc}
\hline \multicolumn{2}{c}{ Lesskilningshluti } & Náttúruvísindahluti \\
Kóngulær & Brúðumeistarinn & Mjólk & Aldauði risaeðlanna \\
4 af $11(36 \%)$ & 5 af $15(33,3 \%)$ & 6 af 15 $(40 \%)$ & 1 af 3 $(33,3 \%)$ \\
\hline
\end{tabular}

Eins og fram kemur í töflu 4 voru 11 orð í textanum um kóngulær sem mátti finna samheiti fyrir í sama tíðniflokki og enska orðið. Í töflu 5 má sjá að af peim voru fjögur orð bæði algengari og lengri en orðin sem höfðu verið valin í pýðingunni. Par kemur einnig fram að hlutfall algengari og lengri samheita var yfir 30\% í textunum fjórum. Detta pýðir að viðmið um að lengri orð hafi tilhneigingu til að vera sjaldgæfari en styttri orð dugar ekki ein sér við pýðingar úr ensku yfir á íslensku. Detta má líka sjá í eftirfarandi dæmum. 
Dæmi 1: (isl) ... höggva tré ... (ens) ... cut down the trees ...

Orðið höggva fellur í sjaldgæfari tíðniflokk en cut. Samheitið saga fellur í sama tíðniflokk og cut og er algengara og styttra en samheitið. Algengara íslenska orðið er pví styttra en pað sjaldgæfara, sem er í samræmi við leiðarvísi OECD.

Dæmi 2: (isl) ... langt skeið myrkurs ... (ens) the long period of darkness ...

Orðið skeið fellur í sjaldgæfari tíðniflokk en tímabil. Samheitið tímabil fellur í sama tíðniflokk og period. Orðið tímabil er lengra og algengara en samheitið.

Dæmi 3: (ísl) ... uppgötvuðu eftirfarandi staðreyndir ... (ens) ... the following facts ...

Orðið eftirfarandi fellur í sjaldgæfari tíðniflokk en following. Samheitið pessar fellur í sama tíðniflokk og following, sem er bæði algengara og styttra en eftirfarandi.

\section{Samantekt}

Af niðurstöðum pessarar rannsóknar má sjá að hlutfall algengustu orða var lægra í öllum textum íslensku pýðingarinnar sem hér voru skoðaðir en í ensku frumtextunum. Hlutfall orða í flokki sjaldgæfustu orðanna var umtalsvert hærra í íslensku textunum en peim ensku. Dá virðist dreifing orða á milli orðtíðniflokka hafa verið jafnari í ensku en íslensku pýðingunum.

Hlutfall pýddra íslenskra orða sem féllu í annan tíðniflokk en samsvarandi ensk orð í upprunalegu textunum var á bilinu 15,2-51,1\%. Fram komu vísbendingar um ákveðið ójafnvægi sem fólst í að tveir priðju hlutar peirra íslensku orða, sem féllu í ólíkan tíðniflokk en ensku orðin, voru sjaldgæfari en samsvarandi ensk orð.

Pá kom í ljós að fækka hefði mátt orðum í ólíkum orðtíðniflokkum pessara fjögurra texta með pví að nota íslenskt samheiti í sama orðtíðniflokki og enska orðið í 33 tilvikum. Til viðbótar hefði mátt nota 13 samheiti úr nærliggjandi orðtíðniflokki. Detta pýðir að ef notuð hefðu verið íslensk samheiti úr sama tíðniflokki og enska orðið hefði hlutfall orða í ólíkum tíðniflokki lækkað úr 22,7\% í 19,5\%. Pá hefði mátt draga enn frekar úr ósamræminu með pví að velja samheiti úr nærliggjandi tíðniflokki.

Hlutfall algengari og lengri samheita var yfir 30\% í textunum fjórum. Petta pýðir að viðmið um að lengri orð hafi tilhneigingu til að vera sjaldgæfari dugar skammt við pýðingar úr ensku yfir á íslensku.

Í hnotskurn benda niðurstöður pessarar rannsóknar til að bæta hefði mátt pýðingu íslensku textanna í PISA-prófinu 2018 með pví að taka mið af orðtíðnilistum við val á orðum. Pannig hefði samræmi íslensku pýðingarinnar og enska frumtextans orðið betra og réttmæti mælingarinnar í PISA-rannsókninni verið betur tryggt.

\section{Umræður}

Markmið pessarar rannsóknar var að kanna samræmi í orðtíðni í íslenskum og enskum textum lesskilnings- og náttúruvísindahluta PISA-prófanna 2018.

Niðurstöður sýna að hlutfall algengustu orða í peim textum sem hér voru rannsakaðir var lægra í íslensku pýðingunum en í ensku frumtextunum. Pá var hlutfall orða í flokki sjaldgæfustu orðanna umtalsvert hærra í íslensku textunum en peim ensku og dreifing orða á milli orðtíðniflokka var meiri og jafnari í ensku textunum en peim íslensku. Einnig kom í ljós að tveir priðju hlutar peirra íslensku orða sem féllu í ólíkan tíðniflokk en ensku orðin voru sjaldgæfari en pau ensku í peim textum sem hér voru teknir til greiningar. Petta leiðir í ljós að fleiri lágtíðniorð voru í íslensku textunum en peim ensku. Niðurstöður gefa einnig ástæðu til að ætla að draga hefði mátt úr ósamræminu með pví að velja íslensk samheiti úr sama eða nærliggjandi tíðniflokki. 
Fjölmargar rannsóknir á ensku hafa leitt í ljós að tengsl eru á milli tíðni orða og pess hversu líklegt er að nemendur pekki orðin (Baayen o.fl., 2007; Balota o.fl., 2006; Gardner o.f1., 1987; Meunier og Segui, 1999; Oldfield og Wingfield, 1965). Niðurstöður pessarar rannsóknar vekja upp pá spurningu hvort íslenski textinn hafi verið hlutfallslega of pungur, p.e. með of mörgum sjaldgæfum orðum, miðað við enska textann, orðum sem eru engu að síður mjög mikilvæg en nemendur pekkja í mismiklum mæli (Biemiller, 2008; Roessingh, 2016). Orðskilningur íslenskra nemenda kann pví að hafa orðið til trafala við úrlausn pessara hluta PISA-prófsins 2018 og pannig hafi hallað á íslenska nemendur umfram pá sem lásu textana á ensku. Meira hafi pví reynt á orðaforða íslenskra nemenda en hæfni peirra til að finna, velja og meta upplýsingar í texta, nýta bakgrunnspekkingu sína og að vega og meta ólík sjónarhorn sem PISA-prófin snúast einmitt um (LaRusso o.fl., 2016; OECD, 2016). Dótt óumflýjanlegt sé að einhver orð á íslensku og ensku falli í ólíka tíðniflokka ættu pýðendur að leitast við að hafa líkt hlutfall orða í orðtíðniflokkum pýðingar og frumtexta, eða gæta jafnvægis á milli fjölda pýddra orða sem eru sjaldgæfari og algengari en orðin í frumtextanum.

Íslenskir nemendur hafa staðið sig einna verst í alpjóðlegum samanburði hvað varðar frammistöðu í lesskilningi og læsi á náttúruvísindi eftir að grunnskóla lýkur samkvæmt niðurstöðum PISA árið 2015, en próunin hefur verið neikvæð frá árinu 2000 (Auður Pálsdóttir, 2017; Menntamálastofnun, 2017; Sigríður Ólafsdóttir og Baldur Sigurðsson, 2017). Fyrstu niðurstöður PISA 2018 eru áætlaðar í lok árs 2019 og geta niðurstöður pessarar rannsóknar verið innlegg í túlkun peirra.

Par sem hlutfall algengari og lengri samheita var meira en priðjungur orða, sem féllu í ólíkan tíðniflokk en á ensku í textunum fjórum, má ætla að almenn viðmið OECD (2016) um að lengri orð hafi tilhneigingu til að vera sjaldgæfari sé hugsanlega misvísandi fyrir íslenska pýðendur. Pess ber að geta að löng orð í íslensku eru gagnsærri en ensk orð og pað skiptir væntanlega máli í pessu sambandi. Langt íslenskt orð getur verið auðskiljanlegt pótt lesandi hafi aldrei séð pað áður, en slíkt er ólíklegt með enskt orð.

Aftur á móti benda niðurstöðurnar til að mikilvægt sé að pýðendur noti orðtíðnilista sem byggja á málheildum til að gæa samræmis í orðavali við upphaflegu útgáfuna.

Rannsóknin hefur takmarkanir líkt og aðrar. Hér var unnið með fjóra texta sem eru aðeins hluti peirra viðfangsefna sem 15 ára nemendur tókust á við árið 2018 og ekki fengu allir pátttakendur sömu textana. Pá parf líka að hafa í huga að ekki er nógu mikið vitað um sambandið á milli tíðni íslenskra orða í Risamálheildinni og orðaforða Íslendinga á misjöfnum aldri. Spyrja parf hvort orðaforði aukist samhliða orðtíðni með hækkandi aldri og hvað megi gera ráð fyrir að hátt hlutfall 15 ára unglinga pekki orð í hverjum tíðniflokki. Orðtíðnilistar hafa pó pær takmarkanir аð par er ekki tekið tillit til margræðni orða. Aðeins er orðflokkur gefinn (t.d. nafnorð, sagnorð, forsetning) en ekki er greint á milli mismunandi merkingar sem sama orð í sama orðflokki getur haft. Dæmi um slíkt er orðið skeið sem kynnt er í niðurstöðum. Í kvenkyni merkir orðið mataráhald en í hvorugkyni tímabil (sem á við í samhengi textans). Dá parf að hafa í huga að orðtíðnilistarnir sem unnið var með byggja á málheildum sem eru ekki að öllu leyti sambærilegar.

Dótt niðurstöður pessarar rannsóknar gefi vísbendingar um að endurskoða purfi leiðbeiningar fyrir pýðendur alpjóðlegra prófa kalla pær einnig á að unninn verði íslenskur hugbúnaður á borð við VocabProfile. Slíkt verkfæri, sem lægi aðgengilegt á vef, fæli ekki aðeins í sér mikinn tímasparnað í vinnu pýðenda við að rýna í fjölbreytni orða út frá orðtíðnilistum. Slíkt verkfæri myndi líka gefa kennurum tækifæri til að fylgjast með framförum nemenda sinna og að finna orð sem gætu reynst nemendum peirra erfið, en einnig nemendum sjálfum og íslenskum almenningi sem rýna vill í eigin skrif.

Í rannsóknum er grundvallaratriði að pær mæli pað sem peim er ætlað að mæla, p.e. að gæta parf að réttmæti rannsókna svo hægt sé að draga trúverðugar ályktanir af niðurstöðum peirra. Ef til vill er ástæða til að benda á að ef Íslendingar spara sér að pýða úr frönsku verður að gera einhverjar aðrar ráðstafanir til að tryggja réttmæti pýðingarinnar. Einhver mikilvæg ástæða hlýtur að vera fyrir pví að pýða verkefnin úr tveimur málum. Í samanburðarrannsóknum eins og PISA parf að 
tryggja að prófin geri sams konar kröfur til pátttakenda sem taka prófin á ólíkum tungumálum pannig að jafnmikið reyni á ólíka færnipætti sem mældir eru. Ef páttur orðaforða er pyngri hjá einum hópi pátttakenda en öđrum dregur pað úr réttmæti samanburðar á milli ríkja. Dví ætti notkun flokkaðra orðtíðnilista sem byggjast á málheildum að vera eftirsóknarverður hluti af vönduðum vinnubrögðum við pýðingar sem lagðar eru til grundvallar svo mikilvægri rannsókn sem PISA-prófin fela í sér.

\section{Analysis of word use in the reading literacy and science literacy parts of PISA 2018: Comparison of the Icelandic translation and the original English version}

Icelandic learners' performance in the reading and science literacy parts of PISA has declined from 2000 to 2015, and the drop in mean scores is one of the most dramatic among participating countries. The percentage of Icelandic participants in the highest proficiency levels has fallen, and the percentage in the lowest levels has risen.

PISA tests are written in two parallel source versions, English and French, and then translated into other languages. OECD publishes guidelines (2016) for translators in which it is stated that translators should avoid simplifying or complicating the vocabulary and the syntax. Due to the direct relationship between word understanding and text comprehension (Laufer \& Ravenhorst-Kalovski, 2010), it is of high importance that translated words be carefully chosen. If there is a higher number of difficult words in one language than another, the readers may have more difficulty in applying the requested reading strategy. Such bias may affect the validity of the measurement.

Studies have demonstrated a strong relationship between the extent to which words are known by individuals and word frequency (Baayen, Wurm \& Aycock, 2007; Balota, Yap \& Cortese, 2006; Gardner, Rothkopf, Lapan \& Lafferty, 1987; Meunier \& Segui, 1999; Oldfield \& Wingfield, 1965).

In the PISA 2018 translation and adaptation guidelines (OECD, 2016, p. 11) it is stated that „longer words tend to be less frequent, more technical and/or more abstract than short words". Nonetheless there is no requirement that translators refer to word frequency lists as an effort to match the frequency of translated words with the words in the original version.

The purpose of this research was to compare the alignment of word frequency in Icelandic translated texts and the original English versions of PISA 2018.

Two text parts were randomly selected from the reading literacy section and two from the natural science section of PISA 2018. Information about the frequency of Icelandic words was obtained from a frequency list based on the Icelandic Gigaword Corpus (Steinpór Steingrímsson, Sigrún Helgadóttir, Eiríkur Rögnvaldsson, Starkaður Barkarson \& Jón Guðnason, 2018; Stofnun Árna Magnússonar 1 íslenskum fræðum, 2017). The software VocabProfile (Cobb, n.d.) was used for the English words, based on two corpuses: the New General Service List and the New Academic Word List. The words were grouped into frequency bands, the most common 1000 words in each band for the most frequent 4000 words, and less frequent words together in one band. When translated Icelandic words did not fall into the same frequency band as the corresponding English words, appropriate Icelandic synonyms were looked for, and the length of the synonyms was compared.

Results of the study indicate that the share of words in the highest frequency band was lower in the Icelandic translated texts than in the English versions, and the share 
of Icelandic words in the lowest frequency band was higher, in all four analysed texts. Additionally, the English words were more evenly distributed between the five frequency bands than the Icelandic words. Furthermore, among the words that did not belong to the same frequency band in Icelandic as in English, the proportion of Icelandic words of lower frequency was higher. If the Icelandic translators had made use of synonyms in the same or adjacent frequency band to the English corresponding words, a better equilibrium between the languages could have been obtained. More than 30\% of more frequent Icelandic words were longer than their less frequent synonyms, which suggests that for Icelandic words it is not a reliable rule that longer words tend to be less frequent than shorter words.

Our findings are an indication that the PISA translation guidelines should include a requirement that translators make use of word frequency lists when choosing words for their translations, so as to make the comparison between countries more valid. If word knowledge is more challenging in one country than another, the impact of the different proficiency factors to be measured is not the same, which may affect the validity of the study. The findings should contribute to the interpretation of PISA results in reading and science literacy for 2018, at least when comparing participants who took the tests in Icelandic and English.

Key words: PISA, translations, vocabulary, word frequency, reading literacy, science literacy

\section{Um höfundana}

Auður Pálsdóttir (audurp@hi.is) er lektor við Menntavísindasvið Háskóla Íslands. Meginrannsóknarsvið hennar eru náttúrufræðimenntun, mat á skólastarfi, kennslufræði samfélags- og náttúrugreina og sjálfbærnimenntun.

Sigríður Ólafsdóttir (sol@hi.is) er lektor við Menntavísindasvið Háskóla Íslands. Meginrannsóknarsvið hennar eru orðaforði, lesskilningur og ritunarfærni nemenda í móðurmáli og öđru máli.

\section{About the authors}

Auður Pálsdóttir (audurp@hi.is) is an assistant professor at The School of Education. Her main research interests include science education, school self-evaluation, pedagogy of science and social science teaching and sustainability education.

Sigríður Ólafsdóttir (sol@hi.is) is an assistant professor at The School of Education. Her main research interests include vocabulary studies, vocabulary acquisition and development, reading comprehension, and writing skills among first and second language learners.

\section{Heimildir}

Arffman, I. (2010). Equivalence of translations in international reading literacy studies. Scandinavian Journal of Educational Research, 54(1), 37-59. doi:10.1080/00313830903488460

Arnbak,A. (2010). To what extent do basic skills predict students' PISA reading score? Í N. Egelund (ritstjóri), Northern Lights on PISA 2009 - focus on reading (bls. 23-43). Kaupmannahöfn: Nordic Council of Ministers.

Auður Pálsdóttir. (2017). Læsi á náttúruvísindi. Vísbendingar úr PISA 2015. Í Menntamálastofnun, Helstu niðurstöður PISA 2015 (bls.36-42). Sótt af https://mms.is/sites/mms.is/files/helstu_nidurstodur_pisa_2015_ prent_-_loka_0.pdf 
Ásdís Bergpórsdóttir. (2016). A brief report on the Icelandic translation of the PISA science test. Sótt af https:// notendur.hi.is/asb23/report.pdf

Baayen, R. H., Wurm, L. H. og Aycock, J. (2007). Lexical dynamics for low-frequency complex words: A regression study across tasks and modalities. The Mental Lexicon, 2(3), 419-463. doi:10.1075/ml.2.3

Balota, D.A.,Yap, M.J. og Cortese, M.J. (2006).Visual word recognition:The journey from features to meaning (a travel update). Í M. J. Traxler og M. A. Gernsbacher (ritstjórar), Handbook of psycholinguistics (2. útgáfa, bls. 285-375). doi:10.1016/B978-012369374-7/50010-9

Biber, D. og Reppen, R. E. (2015). Handbook of corpus linguistics. Cambridge: Cambridge University Press.

Biber, D., Reppen, R. og Friginal, E. (2010). Research in corpus linguistics. Í R. B. Kaplan (ritstjóri), The Oxford handbook of applied linguistics (bls. 548-567). Oxford: Oxford University Press.

Biemiller, A. (2008). Words worth teaching. Columbus, OH: SRA/McGraw-Hill.

Browne, C., Culligan, B. og Phillips, J. (2013). The new general service list. Sótt af http://www.newgeneralservicelist.org/

Chen,Y.-F. og Jiao, H. (2014). Exploring the utility of background and cognitive variables in explaining latent differential item functioning: An example of the PISA 2009 reading assessment. Educational Assessment, 19(2), 77-96. Sótt af http://www.tandfonline.com/doi/abs/10.1080/10627197.2014.903650

Cobb, T. (e.d.). Range for texts v.3 [tölvuhugbúnaður]. Sótt af https://www.lextutor.ca/cgi-bin/range/texts/ index.plht

Cobb, T. (2007). Computing the vocabulary demands of L2 reading. Language Learning and Technology, 11(3), 38-64. doi:10125/44117

Dale, E. og O’Rourke, J. (1981). The living word vocabulary: A national vocabulary inventory. Chicago: World Book - Childcraft International.

Eiríkur Rögnvaldsson, Kristín M. Jóhannsdóttir, Sigrún Helgadóttir og Steinpór Steingrímsson. (2012). Íslensk tunga á stafrænni öld / Icelandic language in the digital age. Í G. Rehm og H. Uszkoreit (ritstjórar), Hvítbókaröð / White Paper Series. Sótt af http://www.meta-net.eu/whitepapers/e-book/icelandic.pdf

Erla Lind Dórisdóttir. (2017). Orðapröskuldur íslenskra grunnskólanemenda á miðstigi: Hlutfall pekktra orða í náttúrufreðitexta og lesskilningur (óútgefin meistararitgerð). Sótt af http://hdl.handle.net/1946/28485

Freyja Birgisdóttir. (2016). Orðaforði og lestrarfærni: Tengsl við gengi nemenda á lesskilningshluta PISA. Sérrit Netlu 2016 - Um loesi. Sótt af http://netla.hi.is/serrit/2016/um_laesi/04_16_laesi.pdf

Friðrik Magnússon. (1988). Hvað er títt? Tíðnikönnun Orðabókar Háskólans. Orð og tunga 1, 1-49. Sótt af https://timarit.is/view_page_init.jsp?pageId=6760074

Friðrik Magnússon og Stefán Briem. (1991). Íslensk orðtíðnibók. Reykjavík: Orðabók Háskólans.

Gardner, M. K., Rothkopf, E. Z., Lapan, R. og Lafferty, T. (1987).The word frequency effect in lexical decision: Finding a frequency-based component. Memory and Cognition, 15(1), 24-28. doi:10.3758/BF03197709

Grisay, A., de Jong, J. H.A. L., Gebhardt, E., Berezner, A. og Halleux-Monseur, B. (2007). Translation equivalence across PISA countries. Journal of Applied Measurement, 8(3), 249-266. Sótt af https://www.ncbi.nlm. nih.gov/pubmed/17804893

Halldóra Jónsdóttir og Pórdís Úlfarsdóttir (ritstjórar). (2018). Íslensk nútímamálsorðabók. Reykjavík: Stofnun Árna Magnússonar í íslenskum fræðum. Sótt af http://islenskordabok.arnastofnun.is/

Hiebert, E. H., Scott, J.A., Castaneda, R. og Spichtig,A. (2019). An analysis of features of words that influence vocabulary difficulty. Education Sciences, 9(1). doi:10.3390/educsci9010008

Hopfenbeck, T. N., Lenkeit, J., El Masri, Y., Cantrell, K., Ryan, J. og Baird, J. (2018). Lessons learned from PISA:A systematic review of peer-reviewed articles on the Programme for International Student Assessment. Scandinavian Journal of Educational Research, 62(3), 333-353. doi:10.1080/00313831.2016.1258726

Hu, M. og Nation, I. S. P. (2000). Unknown vocabulary density and reading comprehension. Reading in a Foreign Language, 13(1), 403-430. Sótt af https://www.victoria.ac.nz/lals/about/staff/paul-nation-pubsdate - 2000s

LaRusso, M., Kim, H.Y., Selman, R., Uccelli, P., Dawson, T., Jones, S., . . Snow, C. (2016). Contributions of academic language, perspective taking, and complex reasoning to deep reading comprehension. Journal of Research on Educational Effectiveness, 9(2), 201-222. doi:10.1080/19345747.2015.1116035 
Laufer, B. og Ravenhorst-Kalovski, G. C. (2010). Lexical threshold revisited: Lexical text coverage, learners' vocabulary size and reading comprehension. Reading in a Foreign Language, 22(1), 15-30.

Martinez, R. og Schmitt, N. (2015).Vocabulary. Í D. Biber og R. Reppen (ritstjórar), The Cambridge handbook of English corpus linguistics (bls. 439-459). Cambridge: Cambridge University Press.

Menntamálastofnun. (2016). Um pýdingarferli PISA. Sótt af https://mms.is/frettir/um-thydingarferli-pisa

Menntamálastofnun. (2017). Helstu niðurstöður PISA 2015. Sótt af https://mms.is/sites/mms.is/files/helstu_nidurstodur_pisa_2015_prent_-_loka_0.pdf

Meunier, F. og Segui, J. (1999). Frequency effects in auditory word recognition: The case of suffixed words. Journal of Memory and Language, 41(3), 327-344. doi:10.1006/jmla.1999.2642

Nation, I. S. P. (2001). Learning vocabulary in another language. Cambridge: Cambridge University Press.

Nation, I. S. P. (2016). Making and using word lists for language teaching and learning. Amsterdam: John Benjamins Publishing Company.

OECD. (2016). PISA 2018 translation and adaptation guidelines. Prag: First meeting of the PISA 2018 national project managers. Sótt af https://www.oecd.org/pisa/pisaproducts/PISA-2018-TRANSLATION-AND-ADAPTATION-GUIDELINES.pdf

OECD. (2017). PISA 2015 assessment and analytical framework: Science, reading, mathematics, financial literacy and collaborative problem solving, revised edition. París: PISA, OECD publishing.

Oldfield, R. C. og Wingfield,A. (1965). Response latencies in naming objects. Quarterly Journal of Experimental Psychology, 17(4), 273-281. doi:10.1080/17470216508416445

Oliveri, M. E. og Ercikan, K. (2011). Do different approaches to examining construct comparability in multilanguage assessments lead to similar conclusions? Applied Measurement in Education, 24(4), 349-366. doi :10.1080/08957347.2011.607063

Rannsóknir og greining. (2016). Ungt fólk 2016: Lýðheilsa ungs fólks í Reykjavík. Niðurstöður rannsóknar meðal nemenda i 8., 9.og 10. bekk árið 2016. Sótt af http://reykjavik.is/sites/default/ files/ymis_skjol/skjol_utgefid_efni/reykjavik_heild_2016_.pdf

Reppen, R. (2010). Using corpora in the language classroom. New York: Cambridge University Press.

Roessingh, H. (2016). Academic language in $\mathrm{K}-12$ : What is it, how is it learned, and how can we measure it? BCTEAL Journal, 1(1), 67-81. Sótt af https://ojs-o.library.ubc.ca/index.php/BCTJ/article/view/235

Romanko, R. (2017). Measuring the vocabulary burden of popular English songs. Vocabulary Learning and Instruction, 6(2). doi:10.7820/vli.v06.2.2187-2759

Sigríður Ólafsdóttir og Baldur Sigurðsson. (2017). Hnignandi frammistaða íslenskra nemenda í lesskilningshluta PISA frá 2000 til 2015: Leiðir til að snúa próuninni við. Netla-Veftímarit um uppeldi og menntun. Sótt af http://netla.hi.is/greinar/2017/ryn/16.pdf

Sigríður Ólafsdóttir, Freyja Birgisdóttir, Hrafnhildur Ragnarsdóttir og Sigurgrímur Skúlason. (2016). Orðaforði og lesskilningur hjá börnum með íslensku sem annað mál:Áhrif aldurs við komuna til Íslands. Sérrit Netlu 2016 - Um laesi. Sótt af http://netla.hi.is/serrit/2016/um_laesi/003.pdf

Steinpór Steingrímsson, Sigrún Helgadóttir, Eiríkur Rögnvaldsson, Starkaður Barkarson og Jón Guðnason. (2018). Risamálheild: A very large Icelandic text corpus. Rádstefnurit LREC 2018, 4361-4366. Sótt af http://www.lrec-conf.org/proceedings/lrec2018/pdf/746.pdf

Stofnun Árna Magnússonar í íslenskum fræðum. (2017). Risamálheildin. Sótt af http://malfong.is/?pg=rmh

Stofnun Árna Magnússonar í íslenskum fræðum. (e.d.). Mörkuð islensk málheild. Sótt af https://arnastofnun. is/is/textasofn

Auður Pálsdóttir og Sigríður Ólafsdóttir (2019).

Greining á orðanotkun í lesskilnings- og náttúruvísindahlutum PISA 2018: Samanburður á íslensku pýðingunni og enska textanum.

Netla - Veftímarit um uppeldi og menntun. Menntavísindasvið Háskóla Íslands.

Sótt af http://netla.hi.is/serrit/2019/altjodlegar_menntakannanir/02.pdf

DOI: https://doi.org/10.24270/serritnetla.2019.31 